\title{
UNA CRÓNICA DE LA EXPULSIÓN DE LOS MORISCOS VALENCIANOS. LOS CUADROS DE LA FUNDACIÓN BANCAJA
}

\author{
Luis E Bernabé Pons
}

Es necesario ser insistente: la expulsión general de los moriscos de España a comienzos del siglo XVII fue un acontecimiento que sacudió a la sociedad hispana contemporánea, un suceso de primer orden que, alcanzando para nosotros carácter de etnicidio, se revistió en la época con rasgos de designio divino. A partir de esta consideración, los testimonios que recogen el éxodo morisco y sus crueles vicisitudes fueron lógicamente abundantes: la mayor parte de ellos achacando a los propios moriscos la responsabilidad de ser echados (ellos, siempre firmes en su "pertinacia”); una mínima parte sacando a la luz los sentimientos de desgarro y piedad que suscitaban en sus convecinos cristianos.

Toda esta literatura fundamentalmente de los apologetas de la expulsión tiene también su reflejo, aunque menos conocido, en las artes plásticas. Un único reflejo conservado, eso sí, pero de extraordinaria importancia. Habiéndose perdido el cuadro "Expulsión de los moriscos" con el que Velázquez ganó el famoso concurso de 1627, la colección de lienzos pertenecientes a Bancaja -y que dan nombre a una de las salas de su sede central en Valencia- queda como el único testimonio plástico contemporáneo a la expulsión.

Los seis cuadros propiedad de Bancaja (el séptimo, "el Embarque de los moriscos en el Puerto de Alicante", pertenece a una colección particular de Valencia) fueron adquiridos en 1980 por la entonces Caja de Ahorros de Valencia a los herederos de los hijos de D. Elías Tormo, su propietario desde 1917. Desde entonces, unos pocos estudios se habían aproximado a ellos sobre todo desde los puntos de vista estético y de indagación acerca de su posible autoría ${ }^{1}$, pero sin insistir en el notable carácter testimonial e ideológi-

1.

Juan TORMO CERVINO, «Siete grandes lienzos de la expulsión de los moriscos valencianos», Valencia Atracción, año 52, n. ${ }^{\circ}$ 505, 1977, pp. 8-9, XII-XIII; Asunción AlEJos MorÁN, «Crónica 
co que los cuadros contenían: precisamente en unos momentos de ebullición de la bibliografía en torno a los moriscos, los cuadros de Bancaja ocupaban un discreto segundo plano, utilizados ocasionalmente para ilustrar y complementar contextos históricos y sociales relacionados.

Fue en diciembre de 1990, en el Congreso Científico "380 è Aniversari de l'Expulsió dels Moriscos", celebrado en Sant Carles de la Ràpita ${ }^{2}$, cuando los cuadros de la expulsión fueron expuestos por vez primera a un nutrido grupo de especialistas en la historia, sociedad y cultura de los moriscos. Convocados muy cerca de uno de los puertos de embarque en 1609 -Los Alfaques- para debatir el antes y el después de la expulsión general, los estudiosos no pudieron menos que sentirse impresionados por unos testimonios históricos de semejante significación. Las opiniones: incomodidad ante lo terrible de lo plasmado, interés ante la contemporaneidad de los lienzos, meditación sobre el momento crucial que se relata; los profesores europeos y de los países árabes allí presentes incorporaron entonces los cuadros de Bancaja a su reflexión acerca de los moriscos.

Pero, aunque más conocidos, los cuadros de Bancaja seguían guardando secretos -todos, en realidad- acerca de su origen y de su factura. Mas gracias a la paciente labor de D. Jesús Villalmanzo, los secretos han sido desvelados merced a sus descubrimientos en el Archivo del Reino de Valencia: por un lado, los cuadros habían salido de los talleres de una serie de pintores valencianos, Pere Oromig, Vicent Mestre, Jerónimo Espinosa y Francisco Peralta, si no de primera fila, tampoco desconocidos para los interesados en la pintura valenciana de los siglos XVI y XVII; por otro lado, el encargo de la factura de los lienzos había partido ni más ni menos que del propio rey Felipe III, quien, con cargo al Patrimonio Real, encargó en 1612 (apenas tres años después de la expulsión de los moriscos valencianos) al marqués de Caracena, virrey de Valencia, que buscase a los pintores apropiados que pudieran ejecutar su petición. Pintores valencianos, se puede suponer en buena lógica, que hubieran podido ser testigos de los embarques en los puertos hacía bien pocos años, o bien que tuvieran información de primera mano o, al menos, que conocieran bien los lugares que habían de pintar siguiendo la voluntad del monarca.

Tales descubrimientos significaban de alguna manera el tomar conciencia de la auténtica y enorme dimensión de los cuadros de Bancaja, en tanto

pictórica de la expulsión de los moriscos valencianos», Cimal. Cuadernos de Cultura Artística, 16, 1982, pp. 50-59; FERNANDO BENITO, «Un plano axonométrico de Valencia diseñado por Mancelli en 1608», Ars Longa, 3, 1992, pp. 29-37.

2. Sus actas aparecieron en el volumen, coordinado por el profesor Míkel de Epalza, L'Expulsió dels Moriscos. Conseqüències en el món islàmic i en el món cristià, Barcelona, Generalitat de Catalunya, 1994, 418 págs. 
en cuanto quedaba demostrada su gran cercanía con los hechos que plasma y, lo que da lugar a mayores reflexiones, su condición de visión "oficial" de la primera y experimental expulsión de moriscos de España, la de los moriscos del Reino de Valencia, en tanto que deseo y encargo de la propia persona que firmó tan tremenda orden.

Así lo entendió -y es de agradecer y felicitar- la Fundación Bancaja de Valencia, que se propuso la realización de una serie de actividades que diesen a conocer los cuadros de su colección dentro del contexto histórico y cultural que los produjo, a partir de los nuevos y sensacionales datos descubiertos y centrándose en los auténticos protagonistas de las imágenes: los moriscos expulsados. En primer lugar, la exhibición pública de los cuadros en unas exposiciones que tuvieron lugar en Valencia (sede central de la Fundación, enero-febrero de 1998), Alicante (sala de exposiciones de la Universidad de Alicante, febrero-marzo de 1998) y Madrid (sede de Bancaja, abril-junio de 1998). Las magníficas exposiciones contaban con los seis cuadros propiedad de Bancaja, más una copia del cuadro del embarque en Alicante, complementados por reproducciones ampliadas de detalles de los cuadros, y los retratos contemporáneos de otros de los grandes protagonistas de la expulsión de los moriscos valencianos: El Patriarca Ribera (Círculo de Salvador Gómez), Felipe III (Antonio Ricci) y Doña Margarita de Austria (Antonio Ricci). El aporte novedoso de las exposiciones lo constituía la exhibición de los documentos descubiertos por Jesús Villalmanzo en los que se desvelaba el origen de las pinturas.

En segundo lugar, la organización de una serie de conferencias con el título general "La Expulsión de los moriscos del Reino de Valencia", a cargo de especialistas que, en las tres sedes de las exposiciones, dieran cuenta de toda la circunstancia vital de esos moriscos que fueron expulsados, conferencias coordinadas -al igual que las exposiciones- por D. José Miranda y que constituyeron un magnífico contrapunto científico para la contemplación de los cuadros. En Madrid, de octubre de 1997 a junio de 1998 intervinieron José María Perceval («Todos son uno: La invención del morisco que nunca existió»), Míkel de Epalza («Los moriscos y sus descendientes, después de la expulsión»), Leonard P. Harvey («Los moriscos y sus escritos: textos en árabe y textos en aljamía»), Gerard A. Wiegers («Los moriscos fuera de España y sus escritos»), Bernard Vincent («La convivencia entre los moriscos y sus límites»), Ricardo García Cárcel («Los moriscos y la Inquisición»), Mercedes García Arenal («Los Moriscos de Granada en Castilla: los problemas de una "emigración forzada"») y Eduardo Subirats («La reforma de la memoria histórica española»). En Valencia intervinieron de nuevo los profesores G.A. Wiegers, Mercedes García Arenal y Míkel de Epalza, mientras que en la Universidad de Alicante las conferencias corrieron a cargo de Manuel Ardit Lucas («La expulsión de los moriscos valencianos y sus consecuencias»), María Jesús Rubiera Mata («La rebelión intelectual de los moriscos») y 
Enrique Cerdán Tato («Crónica de un desencuentro»), siempre con la participación de un público atento y con un cierto impacto en los medios de comunicación. Verba volant: las conferencias pronunciadas en Madrid han dado lugar al libro La expulsión de los moriscos. 14 de octubre de 1997 - 9 de junio de 1998. Valencia, Fundación Bancaja, 1998 (ver Sección "BIBLIOGRAFÍA" en este mismo volumen), en el que ya se incorporan algunas impresiones y reflexiones acerca de la ideología de alguno de los cuadros, curiosamente el que no aparece por ningún lado en la documentación de Villalmanzo (Míkel de Epalza, «Los moriscos y sus descendientes, después de la expulsión (Después del cuadro del desembarco de Orán)».

Scripta manent: en tercer lugar (aunque podría ser el primero por su ideación), la elaboración y publicación de un magnífico catálogo de la exposición (ver Sección "BIBLIOGRAFÍA"), del que hay versión en castellano y versión en valenciano, que recoge el contenido de las exposiciones, más una presentación de los moriscos valencianos y la plasmación de los nuevos descubrimientos por parte de D. Jesús Villalmanzo. Se trata de un catálogo bellamente presentado que reproduce los cuadros de las exposiciones con estupendas ampliaciones fragmentadas, explicados con partes de la minuciosa descripción que de ellos hace al principio Villalmanzo, y que, sin duda, será una obra de referencia para todos aquéllos que deseen aproximarse al traumático hecho de la expulsión de los moriscos valencianos y reflexionar acerca de las ideas y voluntades contenidas en los cuadros ${ }^{3}$, planteándose cuestiones que sin duda sugieren las imágenes de la colección de Bancaja (¿cuál fue el propósito real -en sus dos sentidos- al encargar esos cuadros? ¿Se encargó alguno más que no se conserva? ¿Por qué el propósito de realismo vence en ellos al de alabanza de la Monarquía? ¿Dónde se consiguió la información geográfica para pintar el del desembarco en Orán?...).

Se trata, para concluir, de una magnífica y ambiciosa iniciativa la llevada a cabo por la Fundación Bancaja para poner en cabal conocimiento de un público amplio la magnífica colección de los cuadros de la Expulsión de los Moriscos, unos cuadros que narran unos dolorosos hechos, pero reales hechos, desde el mismo borde temporal de la expulsión para la posteridad. Unos cuadros que deben ponerse en relación con el monumento erigido en el extremo del puerto de Los Alfaques en el Congreso antes aludido, con el mensaje de que nadie vuelva a ver alejado de la tierra que ama. De nuevo, que así sea.

3. Que yo conozca, el catálogo ya ha dado lugar al menos a una publicación de D. Ángel PÉREZ MARTíNEZ, «La expulsión de los moriscos en la pintura valenciana del siglo XVII», en Día 4 que fuera, Villena (Alicante), Ayuntamiento de Villena, 1998, pp. 220-229 y a su inclusión en forma de desplegable, con una nota de Rosa María Bueso, en el dossier sobre Felipe III de la revista La aventura de la Historia, 9 , Madrid, julio de 1999. 